\title{
DISPARITAS GENDER DALAM TINGKAT PENGEMBALIAN INVESTASI PENDIDIKAN DI
} JAWA BARAT

\author{
Diah Nurulia Megasari \& Losina Purnastuti \\ Universitas Negeri Yogyakarta, Indonesia \\ Email: nuruliadiah81@gmail.com
}

\begin{abstract}
Abstrak: Disparitas Gender dalam Tingkat Pengembalian Investasi Pendidikan di Jawa Barat. Investasi yang dilakukan seseorang akan membawa sejumlah manfaat yang kembali pada dirinya sendiri maupun pada lingkungan sekitar. Kembalinya manfaat pada individu yang melakukan investasi pendidikan sering disebut juga tingkat pengembalian investasi pendidikan. Penelitian ini bertujuan untuk mengetahui seberapa besar tingkat pengembalian investasi pendidikan antara tenaga kerja lakilaki dan perempuan di Jawa Barat Tahun 2014. Model yang digunakan adalah model persamaan pendapatan Mincer. Penelitian ini menggunakan data dari SAKERNAS dan diolah menggunakan teknik analisis regresi linier berganda. Hasil penelitian menunjukkan bahwa tingkat pendidikan, potensi pengalaman kerja, potensi pengalaman kerja kuadrat dan jenis kelamin berpengaruh terhadap pendapatan. Semakin tinggi tingkat pendidikan maka tingkat pengembalian investasi pendidikan yang diterima pun semakin besar. Hasil chow test menunjukkan ada perbedaan tingkat pengembalian investasi pendidikan antara tenaga kerja laki-laki dan perempuan. Tenaga kerja perempuan menerima tingkat pengembalian investasi pendidikan lebih tinggi dibanding laki-laki, kecuali pada tingkat pendidikan Diploma.
\end{abstract}

Kata kunci: Tingkat pengembalian investasi pendidikan, tenaga kerja, laki-laki, perempuan.

\begin{abstract}
Abstrak: Gender Disparity in Return to Education in West Java. The investment that one makes will yield a lot of benefits that will return to oneself or the surroundings. The return of the benefits to the individual who makes educational investment is called the return to education. This study aimed to find out the return to education between male and female workers in West Java in 2014. The model employed was the Mincer earnings model. The data in the study were the secondary data from SAKERNAS 2014 with 14,951 selected samples. The analysis technique was multiple regression analysis. The results of the study showed that the educational level, work experience potential, work experience potential squared, and gender affect earnings. The higher the educational level was, the higher return to education was. The results of the chow test showed that there was a difference in the return to education between male and female workers. The female workers had the higher return to education than the male workers, except for the diploma education level.
\end{abstract}

Keywords: return to education, workers, males, females

\section{PENDAHULUAN}

Pendidikan merupakan kunci kemajuan ekonomi suatu masyarakat. Pendidikan ataupun pelatihan yang dilakukan masyarakat akan meningkatkan kemampuan mereka dalam memproduksi barang dan jasa atau dengan kata lain produktivitas mereka meningkat. Hal tersebut sejalan dengan pendapat Kim dan Mohtadi (1992) bahwa pendidikan merupakan salah satu alat dalam 
investasi human capital yang terbukti mampu meningkatkan produktivitas pekerja. Produktivitas tinggi yang dimiliki masyarakat selanjutnya akan meningkatkan pendapatan yang dihasilkan. Demikianlah bagaimana pendapatan yang dimiliki masyarakat akan mendorong kemajuan ekonomi.

Investasi yang dilakukan seseorang dalam bidang pendidikan akan membawa sejumlah manfaat yang kembali pada dirinya sendiri maupun pada lingkungan sekitarnya. Kembalinya manfaat pada individu yang melakukan investasi pendidikan sering disebut juga sebagai tingkat pengembalian investasi pendidikan (return to education). Menurut OECD (2000), tingkat pengembalian (return) yang diterima dapat berupa monetary atau non monetary. Adapula yang menyebutnya economy atau non economy return. Monetary return ada yang bersifat direct (Private) yakni manfaat yang diterima individu berupa peningkatan pendapatan sejalan dengan peningkatan pendidikan yang dilakukannya. Kemudian ada pula yang sifatnya indirect (Society) yakni adanya peningkatan output ekonomi di lingkungan sekitar masyarakat akibat adanya individu yang melakukan investasi pendidikan. Selain monetary return adapula non monetary return baik yang dirasakan oleh invidu itu sendiri maupun masyarakat. Non monetary return dapat berupa peningkatan kesadaran akan kesehatan, penerapan perilaku berdemokrasi yang baik, serta peningkatan aspek-aspek kesejahteraan lain.

Penelitian mengenai tingkat pengembalian investasi pendidikan telah banyak di lakukan. Seperti penelitian yang dilakukan Deolalikar (1993) di Indonesia yang menemukan bahwa tingkat pengembalian untuk perempuan lebih tinggi dibanding lakilaki terutama pada jenjang sekolah menengah dan perguruan tinggi. Demikian halnya dengan penelitian yang dilakukan Purnastuti, dkk. (2011) di Indonesia, Kwack, dkk. (2007) di Korea dan Assadullah (2006) di Bangladesh. Sebagian besar penelitian tersebut menemukan hasil yang konsisten, yakni bahwa tingkat pengembalian pendidikan untuk perempuan lebih tinggi dibanding laki-laki. Meskipun telah didapat hasil yang konsisten, namun penelitian dalam lingkup provinsi belum banyak dilakukan. Lingkup yang lebih kecil memungkinkan adanya hasil yang berbeda, sesuai dengan karakteristik sosial dan budaya masyarakatnya.

\section{METODE}

Penelitian ini menggunakan data Survey Angkatan Kerja Nasional (SAKERNAS) Provinsi Jawa Barat tahun 2014. Sampel yang digunakan adalah penduduk berusia 15-65 tahun yang berstatus bekerja, memiliki pendapatan dan memberikan informasi lengkap tentang variabel yang diperlukan dalam penelitian ini.

Estimasi tingkat pengembalian investasi pendidikan dilakukan dengan menggunakan metode OLS. Sedangkan untuk melihat apakah terdapat perbedaan antara tingkat investasi pendidikan pekerja laki-laki dan pekerja perempuan digunakan analisis chow test. Model persamaan pendapatan mengadopsi model Mincer (1974) yang dikembangkan, dan disajikan dalam persamaan berikut:

$\operatorname{LnP}_{i}=\beta_{0}+\beta_{1}$ DumTP $_{i}+\beta_{2} \mathrm{PK}_{i}+\beta_{3} \mathrm{PK}_{i}^{2}+\beta_{4} \mathrm{JK}_{i}+$ $\varepsilon_{\mathrm{i}}$ 
$\mathrm{LnP}_{\mathrm{i}}=$ logaritma natural pendapatan individu

$\mathrm{TPi}=$ dummy tingkat pendidikan individu

$\mathrm{PK}_{\mathrm{i}} \quad=$ potensi pengalaman kerja

$\mathrm{PK}_{\mathrm{i}}{ }^{2}=$ potensi pengalaman kerja kuadrat

$\mathrm{JK}_{\mathrm{i}} \quad=$ dummy jenis kelamin individu

$\varepsilon_{\mathrm{i}} \quad=$ eror

$\beta=$ koefisien regresi

Kemudian dengan menggunakan model persamaan di atas, rata-rata tingkat pengembalian investasi tiap tingkat pendidikan dapat dihitung dengan mengacu pada metode yang digunakan Deolalikar (1993) yaitu:

$r_{K}=\frac{\beta \kappa}{n \kappa}$

$r_{\mathrm{k}}=$ tingkat pengembalian per tingkat sekolah

$\beta_{K}=$ koefisien tingkat pendidikan

$\mathrm{nk}=$ lama sekolah

\section{HASIL DAN PEMBAHASAN}

Diskusi tentang hasil beserta pembahasannya akan diawali dengan penyajian beberapa data yang mendeskripsikan kondisi responden terkait variabel pendapatan, pendidikan yang dikaitkan dengan gender. Diawali dengan variabel pendapatan. Tabel 1 menyajikan distribusi pendapatan pekerja laki-laki dan perempuan di Jawa Barat.

Pada Tabel 1 tampak jelas bahwa terdapat perbedaan yang sangat nyata pada pola pendapatan tenaga kerja laki-laki dan perempuan di Jawa Barat. Meskipun pendapatan terendah pada kedua kelompok gender ini sama, yaitu sebesar Rp50.000, namun bila ditinjau dari rata-rata dan besarnya pendapatan tertinggi yang diperoleh masing-masing kelompok gender, akan Nampak jelas perbedaannya. Pekerja laki-laki memperoleh pendapatan rata-rata 24\% lebih tinggi dibandingkan pekerja perempuan. Sedangkan data pendapatan tertinggi menunjukkan bahwa pendapatan tertinggi pekerja laki-laki 23\% lebih tinggi dibandingkan dengan pendapatan tertinggi pekerja perempuan. Kemudian jika dibandingkan dengan rata-rata Upah Minimum Kabupaten/Kota (UMK) di Jawa Barat yakni sebesar Rp 1.636.579 maka ratarata pendapatan tenaga kerja laki-laki di Jawa Barat sudah di atas UMK dan telah melebihi hasil survey kebutuhan hidup layak, namun lain halnya dengan perempuan yang masih di bawah rata-rata UMK.

Perbedaan pendapatan antara tenaga kerja laki-laki dan perempuan dapat dikaitkan dengan tingkat pendidikan. Berdasarkan penghitungan menggunakan perbandingan nilai rata-rata pendapatan di tiap tingkat pendidikan, maka terlihat kecenderungan pendapatan antara laki-laki dan perempuan sebagaimana tersaji pada gambar 1.

Tabel 1. Distribusi Pendapatan Tenaga Kerja

\begin{tabular}{lrr}
\hline Pendapatan & Laki-laki & Perempuan \\
\hline Terendah & Rp50.000 & Rp50.000 \\
Tertinggi & Rp69.650.000 & Rp84.650.000 \\
Rata-rata & Rp1.710.462 & Rp1.382.827 \\
\hline
\end{tabular}


Jurnal Economia, Volume 12, Nomor 1, April 2016

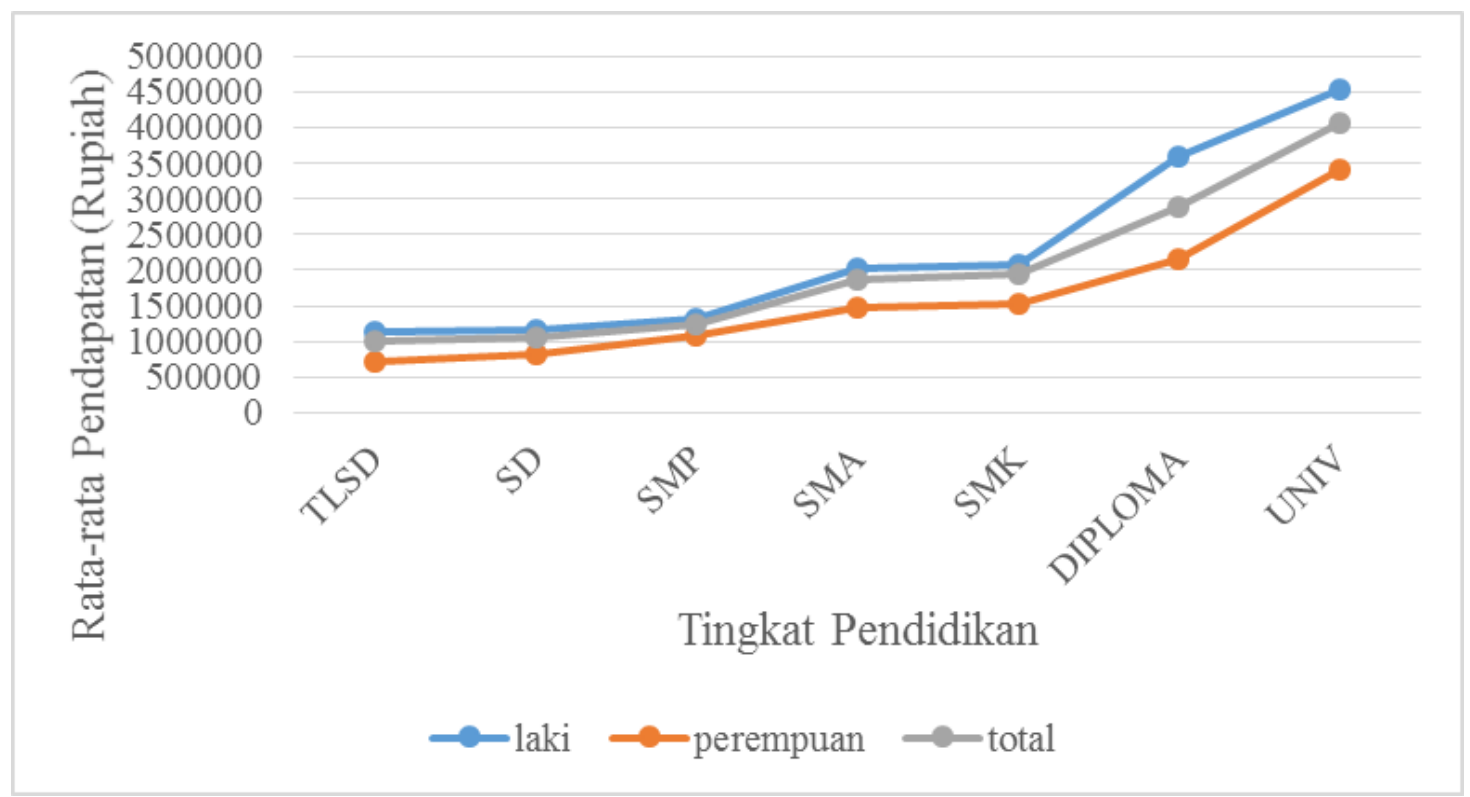

Gambar 1. Rata-Rata Pendapatan Laki-laki dan Perempuan Berdasarkan Tingkat Pendidikan

Gambar 1. Menyiratkan pesan bahwa baik pada pekerja laki maupun perempuan pendapatan rata-rata akan meningkat seiring dengan meningkatnya tingkat pendidikan pekerja tersebut. Namun demikian pada tiap jenjang pendidikan yang sama pendapatan rata-rata pekerja perempuan selalu lebih rendah dibandingkan pendapatan rata-rata pekerja laki-laki. Bila dicermati lebih seksama kan nampak bahwa semakin tinggi jenajng pendidikan maka semakin lebar perbedaan pendapatan rata-rata dua kelompok gender ini. Terkait dengan hal tersebut mungkin dapat dijelaskan dengan hasil penemuan Soegijanto (2003) yang menjelaskan bahwa dari 587 lowongan kerja yang ditawarkan, $31,3 \%$ di antaranya mensyaratkan jenis kelamin tertentu. Dari 31,1\% tersebut, 20,6\% di antaranya ditujukan untuk laki-laki, dan $10,7 \%$ untuk wanita. Artinya, untuk jenis pekerjaan/jabatan yang mensyaratkan jenis kelamin tertentu, peluang kerja lulusan

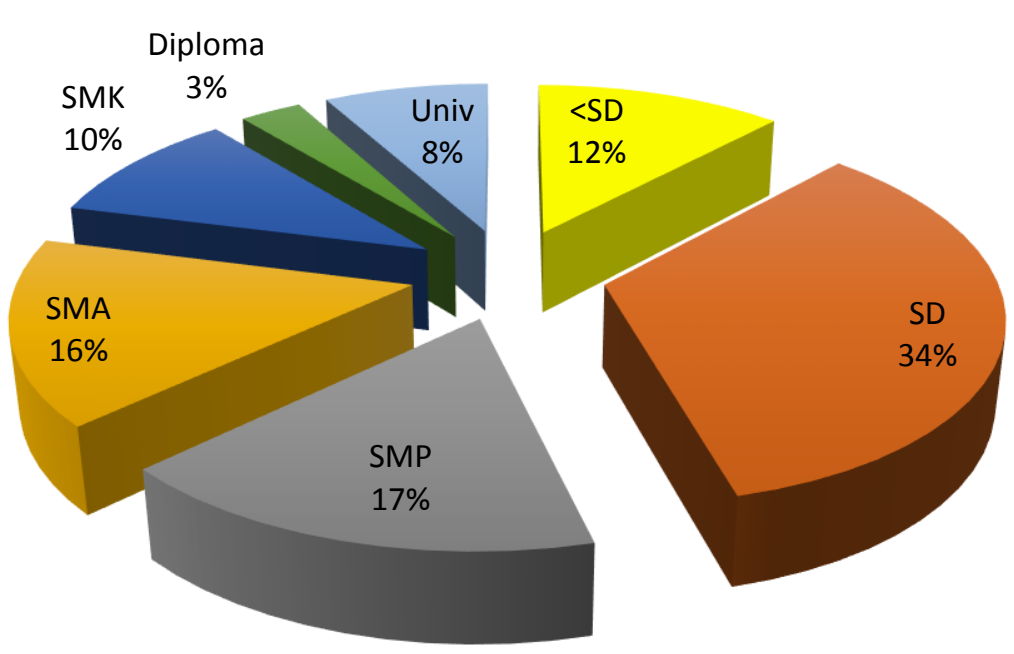

Gambar 2. Distribusi Jenjang pendidikan Pekerja di Jawa Barat tahun 2014 
perguruan tinggi laki-laki dua kali lebih besar dibandingkan wanita.

Beralih ke variabel pendidikan. Gambar 2. Mmenyajikan sebaran jenjang pendidikan pekerja di Jawa Barat tahun 2014 yang menjadi sampel dalam penelitian ini.

Pola sebaran tingkat pendidikan tenaga kerja dapat digunakan untuk mengindikasikan kualitas tenaga kerja di Jawa Barat. Kelompok terbesar pekerja adalah pekerja dengan pendidikan SD dan tidak lulus SD/tidak pernah sekolah sebesar 46\%. Kelompok terbesar kedua adalah pekerja dengan ijazah SMP sebanyak $17 \%$. Pekerja dengan kualifikasi pendidikan tinggi (diploma dan srjana) hanya sebesar $20 \%$. Melihat gambaran data tersebut dapat disimpulkan bahwa pekerja di Jawa Barat masih didominasi oleh tenaga kerja kurang terdidik.

Jika data mengenai sebaran pekerja berdasar jenjang pendidikan kita bedakan berdasar gender, akan diperoleh gambaran seperti yang ditampilkan pada gambar 3 .
Secara garis besar distribusi jenjang pendidikan berdasarkan gender meunjukkan bahwa pada pendidikan sekolah menengah ke bawah secara relatif pekerja laki-laki lebih banyak dari pada pekerja perempuan. Sedangkan pada jenjang pendidikan tinggi, yaitu diploma dan universitas pekerja perempuan persentasenya lebih banyak.

Selanjutnya beralih pada estimasi tingkat pengembalian investasi pendidikan. Tabel 2 . menunjukkan ringkasan hasil estimasi tingkat pengembalian investasi pendidikan dengan pendekatan OLS. Model standar Mincer digunakan untuk melihat hubungan antara Pendapatan (Ln) dengan tingkat pendidikan, potensi pengalaman kerja, potensi pengalaman $\mathrm{kerja}^{2}$, dan jenis kelamin. Estimasi dibedakan berdasar gender, sehingga diperoleh tiga estimasi: estimasi untuk semua sampel, estimasi untuk sampel pekerja laki-laki, dan estimasi untuk pekerja perempuan.

Pada Tabel 2. Dapat dilihat bahwa semua variabel eksplanatori secara signifikan

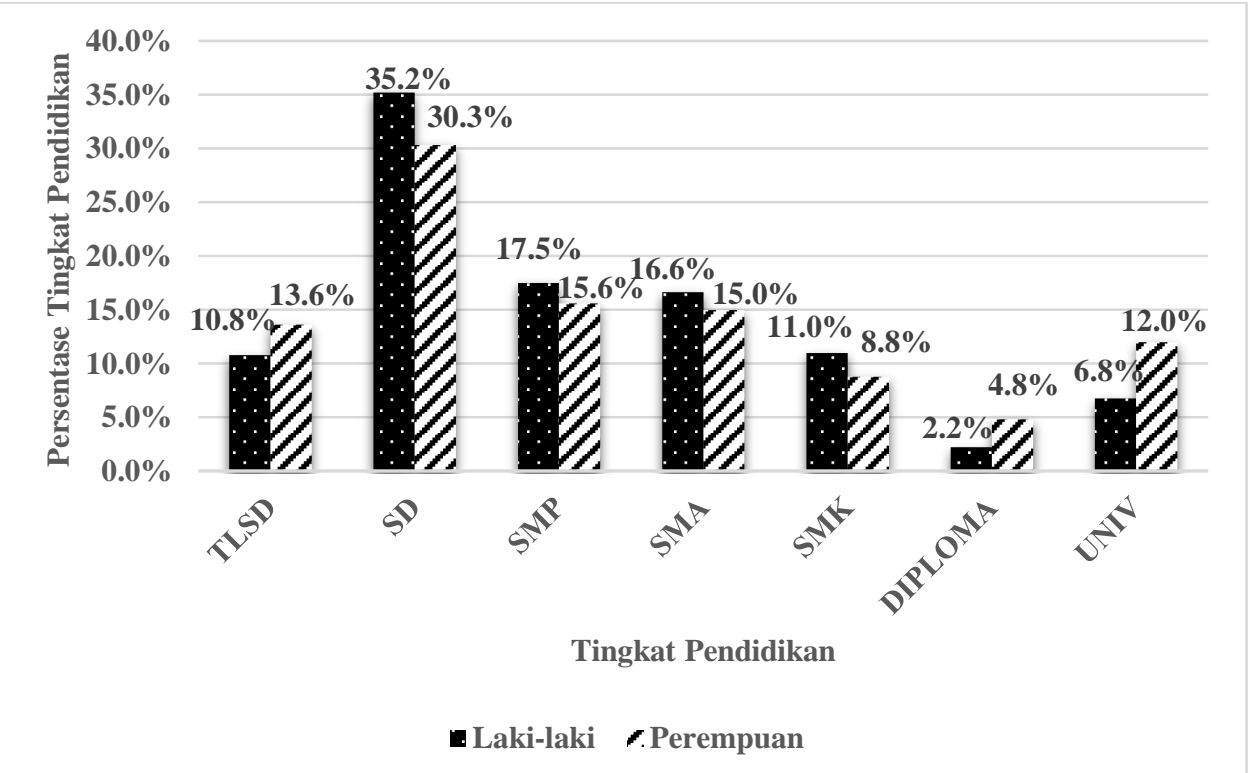

Gambar 3. Sebaran Pekerja di Jawa Barat tahun 2014 Berdasar Jenjang Pendidikan dan Gender 
Jurnal Economia, Volume 12, Nomor 1, April 2016

Tabel 2. Ikhtisar Hasil Estimasi dengan Pendekatan OLS

\begin{tabular}{|c|c|c|c|}
\hline Variabel & Sampel Total & Laki-laki & Perempuan \\
\hline \multirow{2}{*}{ Konstanta } & 12,9169 & 13,1771 & 13,0281 \\
\hline & $(0,0286)^{* * *}$ & $(0,0321)^{* * *}$ & $(0,0566)^{* * *}$ \\
\hline \multirow{2}{*}{ SD } & 0,0460 & 0,0284 & 0,0560 \\
\hline & $(0,0220)^{* *}$ & $(0,0249)$ & $(0,0442)$ \\
\hline \multirow{2}{*}{ SMP } & 0,6427 & 0,2307 & 0,4372 \\
\hline & $(0,0259)^{* * *}$ & $(0,0290)^{* * *}$ & $(0,0545)^{* * *}$ \\
\hline \multirow{2}{*}{ SMA } & 0,6427 & 0,5925 & 0,7219 \\
\hline & $(0,0289)^{* * *}$ & $(0,0295)^{* * *}$ & $(0,0558)^{* * *}$ \\
\hline \multirow{2}{*}{ SMK } & 0,7464 & 0,7106 & 0,8122 \\
\hline & $(0,0264)^{* * *}$ & $(0,0320)^{* * *}$ & $(0,0620)^{* * *}$ \\
\hline \multirow{2}{*}{ Diploma } & 1,0896 & 1,1261 & 1,0374 \\
\hline & $(0,0406)^{* * *}$ & $(0,0509)^{* * *}$ & $(0,0715)^{* * *}$ \\
\hline \multirow{2}{*}{ Univ } & 1,3172 & 1,3054 & 1,3272 \\
\hline & $(0,0299)^{* * *}$ & $(0,0354)^{* * *}$ & $(0,0571)^{* * *}$ \\
\hline \multirow{2}{*}{ PPK } & 0,0314 & 0,0460 & 0,0177 \\
\hline & $(0,0016)^{* * *}$ & $(0,0018)^{* * *}$ & $(0,0029)^{* * *}$ \\
\hline \multirow{2}{*}{ PPK_kuadrat } & $-0,0005$ & $-0,0006$ & $-0,0003$ \\
\hline & $(0,0000297)^{* * *}$ & $(0,0000348)^{* * *}$ & $(0,0000568)^{* * *}$ \\
\hline \multirow{2}{*}{ Laki-laki } & 0,3399 & & \\
\hline & $(0,0129356)^{* * *}$ & & \\
\hline $\mathrm{R} 2$ & 0,2526 & 0,2455 & 0,2192 \\
\hline $\mathrm{N}$ & 14951 & 10453 & 4498 \\
\hline \multicolumn{4}{|c|}{ Chow $\quad$ Test $\quad(\mathrm{F}$} \\
\hline Test) & 121,47 & & \\
\hline prob F & {$[0,0000]$} & & \\
\hline
\end{tabular}

Catatan: angka dalam kurung adalah Standar error .

$*, * *$ dan $* * *$ menandakan tingkat signifikansi sebesar $10 \%, 5 \%$ dan $1 \%$

berkontribusi mempengaruhi variabel dependen, dengan tingkat signifikansi $5 \%$ dan $1 \%$, kecuali variabel dummy jenjang pendidikan Sekolah Dasar ketika sampel dipisah antara pekerja laki-laki dan perempuan. Dengan merujuk formula yang digunakan oleh Deolalikar (1993), besarnya tingkat pengembalian investasi pendidikan pada tiap jenjang pendidikan disajikan dalam gambar 4.

Gambar 4 mengimplikasikan beberapa pesan intuisi ekonomi. Pertama besarnya tingkat pengembalian investasi pendidikan berbanding lurus dengan jenjang pendidikan. $\mathrm{Hal}$ ini sejalan dengan temuan pada penelitian yang dilakukan oleh Purnastuti dkk (2013) dengan data nasional. Kondisi ini memperkuat pesan pentingnya investasi pendidikan dan sekedar berbekal pendidikan menengah apalagi pendidikan dasar tidaklah cukup. Kedua, Tingkat pengembalian investasi pendidikan pada pekerja perempuan selalu lebih tinggi dibandingkan pekerja laki-laki kecuali pada jenjang 


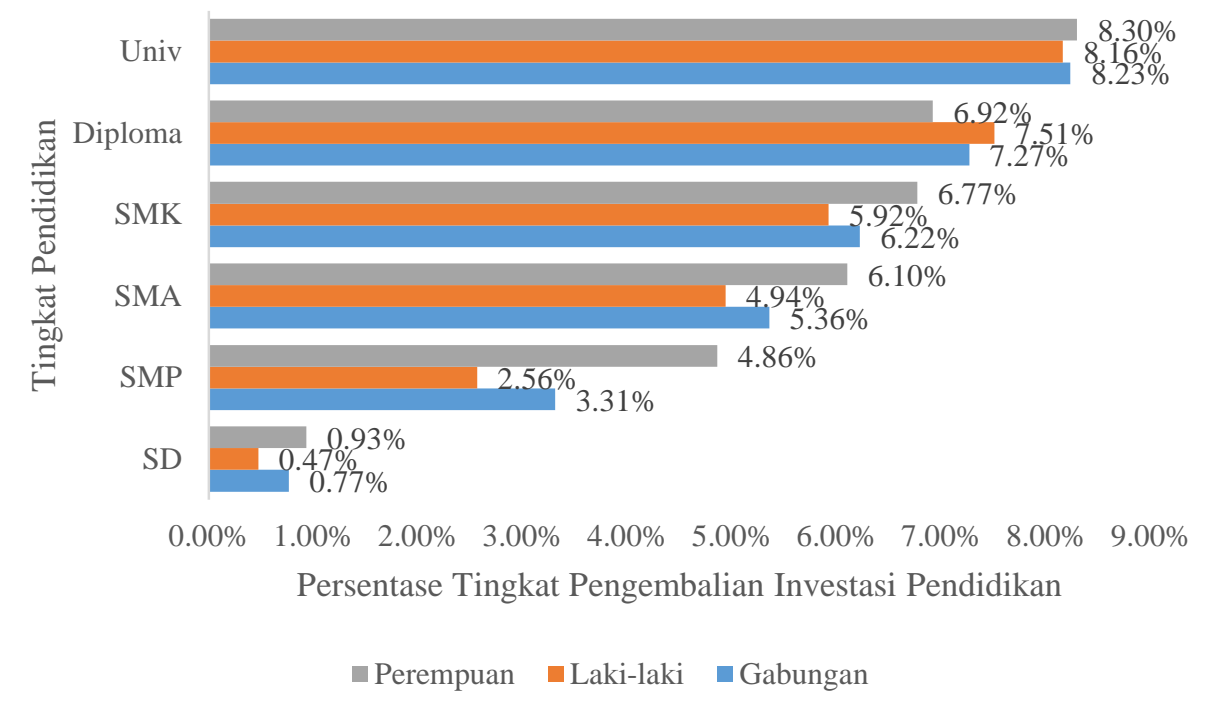

Gambar 4. Tingkat Pengembalian Investasi Pendidikan Berdasar Jenjang Pendidikan dan Gender Tenaga Kerja di Jawa Barat Tahun 2014

pendidikan diploma. Hal ini juga selaras dengan temuan beberapa penelitian yang sudah dilakukan sebelumnya baik dengan data Indonesia maupun data dari berbagai Negara (Lihat Deolalikar (1993), Magdalyn (2013) dan Purnastuti dkk (2011)) dan menguatkan argumentasi bahwa investasi pendidikan pada perempuan sangat patut untuk diprioritaskan.

Menurut Mincer (1974), selain faktor pendidikan formal, "on job training" juga akan berpengaruh pada pendapatan seorang pekerja. Variabel tersebut dapat diwakili oleh pengalam kerja seseorang. Dalam penelitian ini pengalaman kerja diukur dengan formula sebagai berikut umur - (lamanya tahun mengenyam pendidikan + usia resmi untuk memasuki pendidikan SD yaitu 7 tahun).

Variabel potensi pengalam kerja berpengaruh signifikan terhadap pendapatan pada ketiga kelompok sampel dengan tingkat signifikansi $1 \%$. Hasil penelitian ini sesuai dengan penelitian yang telah dilakukan sebelumnya, seperti
Magdalyn (2013) di Indonesia, Kifle (2007) di Eritrea dan Kwack dkk (2007) di Korea dimana variabel potensi pengalaman kerja pada penelitian yang telah mereka lakukan memiliki arah yang positif dan signifikan berpengaruh terhadap pendapatan.

Jika dilihat berdasarkan kelompok gender terlihat bahwa pada sampel laki-laki pengaruh potensi pengalaman kerja 0,028 poin lebih tinggi dibandingkan pekerja perempuan. Hal ini dapat dimaknai bahwa besarnya kenaikan pendapatan yang disumbang oleh kenaikan tahun pengalaman kerja pekerja laki-laki hampir tiga kali lipat tenaga kerja perempuan. Kondisi ini perlu dikaji lebih spesifik lagi dengan suatu kajian khusus untuk menjawab apakah perbedaan tersebut dapat dimaknai sebagai perbedaan peningkatan produktivitas antara pekerja laki-laki dan perempuan atau perbedaan yang disebabkan oleh faktor lain misalnya diskriminasi perlakuan antara pekerja lakilaki dan perempuan yang lebih menguntungkan pekerja laki-laki. 
Koefisien variabel dummy gender adalah 0,3399. Menurut Halvorsen dan Palquist (1980) koefisien variabel dummy tidak bisa secara langsung diinterpretasikan sebagai persentase pengaruh variabel tersebut, melainkan harus dilakukan penghitungan pengaruh relatif. Sehingga pengaruh relatif dari variabel jenis kelamin laki-laki dalam penelitian ini adalah sebesar 0.4048 yang diperoleh dari (exp(0.3399) - 1). Artinya tenaga kerja laki-laki menghasilkan pendapatan 40,48\% lebih tinggi dibanding tenaga kerja perempuan. $\mathrm{Hal}$ ini mengindikasikan kemungkinan adanya diskriminasi gender di pasar tenaga kerja.

Dugaan adanya diskriminasi gender di pasar tenaga kerja merupakan salah satu bentuk ketidakadilan gender. Didasarkan pada bentuk-bentuk ketidakadilan gender menurut Fakih (2008), rendahnya pendapatan yang diterima perempuan dibanding laki-laki merupakan salah satu ketidakadilan gender dalam bentuk marginalisasi perempuan. Marginalisasi perempuan dalam hal ini disebabkan oleh kebijakan perusahaan yang memberikan perempuan gaji lebih kecil dibanding lakilaki. Selain itu perempuan juga menghadapi ketidakadilan gender berupa beban kerja ganda. Mayoritas masyarakat menganggap bahwa perempuan memiliki kewajiban dan tanggung jawab melakukan pekerjaanpekerjaan domestik sedangkan tidak untuk laki-laki yang sudah bekerja, sehingga perempuan yang memiliki pekerjaan diluar rumah akan terbebani dengan adanya pekerjaan domestik yang harus dilakukan.

\section{SIMPULAN}

Berdasarkan data yang dipaparkan di atas dapat dilihat adanya kesenjangan pendapatan yang cukup tinggi di Jawa Barat. Kesenjangan pendapatan pada tenaga kerja perempuan lebih besar dibanding laki-laki. Berdasarkan hasil regresi dan penghitungan pengaruh relatif, tenaga kerja laki-laki menerima pendapatan 40,5\% lebih tinggi dibanding tenaga kerja perempuan. Selain itu jika dilihat berdasarkan potensi pengalaman kerja, ditemukan tiap tambahan 1 tahun potensi pengalaman kerja berpengaruh terhadap peningkatan pendapatan sebesar 4,6\% pada tenaga kerja laki-laki dan 1,8\% pada tenaga kerja perempuan. Tingkat pendidikan berpengaruh terhadap peningkatan pendapatan tenaga kerja di Jawa Barat. Secara statistik ditemukan adanya perbedaan tingkat pengembalian investasi pendidikan antara laki-laki dan perempuan, di mana perempuan menerima tingkat pengembalian investasi pendidikan lebih tinggi dibanding laki-laki di semua tingkat pendidikan. Namun demikian jika dilihat dari aspek pendapatan, rata-rata pendapatan yang diterima tenaga kerja lakilaki lebih tinggi dibanding perempuan. Hal ini mungkin disumbang oleh adanya diskriminasi gender di pasar tenaga kerja.

\section{DAFTAR PUSTAKA}

Assadullah, M. N. (2006). Returns to Education in Bangladesh. Education Economics 14 (4): 453-468.

Deolalikar, Anil. (1993). Gender Differences in the Returns to Schooling and in School Enrollment Rates in Indonesia. Journal of Human Resources. 28 (4), 899-932. 
Fakih, Mansour. (2008). Analisis Gender dan Transformasi Sosial. Yogyakarta: Pustaka Pelajar.

Halvorsen, R. \& R. Palmquist. (1980). The Interpretation of Dummy Variables in Semilogarithmic Equations. American Economic Review, 7(3): 474-475.

Kifle, T. (2007). The Private Rate of Return to Schooling: Evidence from Eritrea. Essays in Education 21: 77-99.

Kim, S dan Mohtadi, H. (1992). Education, Job Signaling, and Dual Labor Markets in Developing Coutries. Diakses dari: https://www.ageconsearch.umn.edu, pada 11 Agustus 2015.

Kwac S. Y., dkk. (2007). Gender Earning Gaps and Return to Schooling in Korea. Journal of Economic Research. 79-101.
Magdalyn, A. (2013). The Rate of Return: The Case of Indonesia. Institute of Social Studies.

Mincer, J. A. (1974). Schooling, Experience, Earnings. Diakses dari: http://www.nber.org/chapters/c3654.p df, pada 20 Februari 2015.

OECD. (2000). Estimating Economic and Social Returns to Learning: Session 3 Issues for Discussion.

Purnastuti, L., dkk. (2011). Economic Return to Schooling in a Less Developed Country: Evidence for Indonesia. Diakses dari: http://kastoria.teikoz.gr/icoae2/, pada 20 Desember 2014.

Purnastuti, L., Miller, P., dan Salim, R. (2013). Decilining Rates of Return to evidence for Indonesia. Bulletin of Indonesia Economic Studies. 49(2), 213-236. 